\title{
Plastid DNA Analysis Reveals Cryptic Hybridization in Invasive Dalmatian Toadiflax (Linaria dalmatica) Populations
}

\author{
Andrew Boswell, Sharlene E. Sing, and Sarah M. Ward*
}

\begin{abstract}
Gene flow between Dalmatian toadflax (DT) and yellow toadflax (YT), both aggressive invaders throughout the Intermountain West, is creating hybrid populations potentially more invasive than either parent species. To determine the direction of gene flow in these hybrid populations, species-diagnostic cytoplasmic markers were developed. Markers were based on polymerase chain reaction-restriction fragment length polymorphism (PCRRFLP) polymorphisms in the trnT-D chloroplast DNA (cpDNA) region digested with $A l u 1$, and single-nucleotide polymorphisms (SNPs) in the matK and trnL-F chloroplast-barcoding regions. Four hybrid toadflax populations sampled from Colorado, Montana, and Washington contained both DT and YT cytoplasm, with YT predominating; 25 individuals from a fifth hybrid population from Idaho all had identical YT cpDNA haplotypes. Thirteen plants from two Colorado populations, assumed to be DT based on morphology and geographic isolation from any known YT population, were found to have YT cpDNA haplotypes. These results indicate that gene flow between invasive YT and DT populations is more widespread that previously realized and confirms that cryptic introgression of YT alleles has occurred in multiple western U.S. DT populations. The presence of YT genetic material in presumed DT populations may negatively affect host recognition and establishment by biocontrol agents used for toadflax management.
\end{abstract}

Nomenclature: Dalmatian toadflax, Linaria dalmatica (L.) P. Mill.; yellow toadflax, Linaria vulgaris P. Mill. Key words: cpDNA, DNA barcoding, cryptic hybridization, gene flow, haplotype.

Two toadflax species-Dalmatian toadflax [Linaria dalmatica (L.) P. Mill.] and yellow toadflax (L. vulgaris P. Mill.) - are widespread invaders in North America. The native range of Dalmatian toadflax (DT) extends from the eastern Mediterranean to northern Iran (Alex 1962). This plant was first introduced into the United States in the late 1800s and is now listed as a noxious weed in 12 states and three Canadian provinces (USDA-NRCS 2016; Vujnovic and Wein 1997). Yellow toadflax (YT) is native to temperate Eurasia and was brought to the eastern United States in the late 1600s by European settlers (Mack 2003). It has since spread to all the lower 48 states, Alaska, and most of Canada and is listed as a noxious or invasive species

\section{DOI: $10.1614 /$ IPSM-D-16-00003.1}

* First and third authors: Graduate student and Associate Professor (ORCID: 0000-0002-9288-1110), Department of Soil and Crop Sciences, Colorado State University, Fort Collins, CO 80523; second author: Research Entomologist, Rocky Mountain Research Station, U.S. Department of Agriculture-U.S. Forest Service, Bozeman, MT 59717. Corresponding author's E-mail: sarah.ward@colostate.edu or both in seven U.S. states (USDA-NRCS 2016). Both these toadflax species are perennial forbs that typically colonize disturbed areas (Arnold 1982; Vujnovic and Wein 1997), although YT has also invaded intact, native plant communities in western U.S. national parks (Pauchard et al. 2003) and high-elevation wilderness areas (Sutton et al. 2007). Both YT and DT are obligate outcrossers, capable of clonal patch expansion via roots and rhizomes (Saner et al. 1995; Vujnovic and Wein 1997), and both species have high levels of genetic diversity within and among populations (Brown 2008; Ward et al. 2008).

Although interspecific hybridization is common within Linaria (Sutton 1988), there is little overlap between the native ranges of YT and DT, and field hybridization between these species has not been reported in Eurasia. In the western United States, however, hybridization between YT and DT at multiple sites of coinvasion has been confirmed (Ward et al. 2009). The two species have slightly different habitat preferences: DT tolerates poor soil and is generally found on dry, open slopes, whereas YT prefers a moister habitat with more-fertile soil. However, varied local topography at disturbed sites, such as logged areas or abandoned mine tailings, often provides suitable micro- 


\section{Management Implications}

Yellow toadflax (YT) and Dalmatian toadflax (DT) are not reported to hybridize in their native European ranges, but crosspollination between these two invasive species has been confirmed in several Rocky Mountain states. This produces novel hybridtoadflax populations that are more vigorous and robust than either parent species, presenting even greater management challenges. Experimental hand-pollinations under controlled greenhouse conditions to produce hybrid toadflax plants previously showed that hybrids were more likely to result from pollination of YT by DT than vice versa, and results of DNA analysis in this study indicate this is also true when crosspollination occurs in the field. Hybrid toadflax presents particular problems for biocontrol. Two stem-boring weevils, Mecinus janthinus and Mecinus janthiniformis, are released as approved biocontrol agents on YT and DT, respectively; however, each of these weevils exhibits a strong preference for its natural host toadflax species. Whether weevils will establish on, and control, hybrid toadflax infestations is unknown. An unexpected finding of this study was that some Colorado toadflax populations, presumed to be pure DT based on their morphology and habitat, in fact, contained YT DNA. This is most likely the result of previous hybridization between YT and DT, followed by repeated crossing back to DT, and suggests that hybridization between these two invasive toadflaxes is more widespread and has been occurring for longer than previously realized. The presence of DNA from the nonpreferred toadflax species in a host-plant population may explain why weevil releases fail to establish at apparently favorable sites, and undetected transfer of DNA between YT and DT could undermine the efficacy of biocontrol in managing toadflax invasion.

habitats for both toadflax species in close proximity. YT and DT also share several insect pollinators; some of which, can fly up to $3.2 \mathrm{~km}$ (2 mi) (Arnold 1982; De ClerckFloate and Richards 1997), facilitating pollen transfer among nonadjacent populations.

Early generation (F1 and BC1) hybrids between YT and DT are fertile, outcrossing, clonal perennials (Ward et al. 2009). In a common garden study reported in Turner (2012), F1 and BC1 toadflax hybrids exhibited heterosis for several vegetative and reproductive traits; hybrids also had an extended flowering period that overlapped with the early summer flowering of DT and the late summer flowering of YT, increasing the potential for backcrossing to either parent species. Consequently, hybrid toadflax populations in the field are likely to be a complex and genetically novel mix. Heterotic, early generation hybrids can persist and spread via clonal perennation; F2 and later segregating generations contain diverse recombinant genotypes on which local selection can act; and additional adaptive traits can be introgressed into one or both parent species via recurrent backcrossing with hybrid progeny.

Asymmetric gene flow, in which one species is more likely than the other to be the female parent of viable hybrid progeny, is a well-documented phenomenon in interspecific hybridization (Lewis and Crowe 1958; Tiffin et al. 2001). Possible causes of asymmetric gene flow in plants include the relative abundance of each parent species at the hybrid site (e.g., as reported in Magnolia by Muranishi et al. 2013), differences in flower morphology (e.g., as described in Eucalyptus by Field et al. 2011), pollinator behavior (e.g., as reported in Yucca by Starr et al. 2013), and postmating reproductive barriers resulting in differential pollen success (e.g., as described in Silene by Rahme et al. 2009). In a series of controlled, reciprocal hybridizations between YT and DT, carried out by Ward et al. (2009), a greater proportion of hand-pollinated crosses with YT as the female parent produced viable seed (49.1\%) compared with those with DT as the female parent $(10.1 \%)$. These results suggest asymmetric hybridization between YT and DT, because of differential pollen success or variability in nuclear-cytoplasmic compatibility or both between reciprocal crosses. If a similar pattern of gene flow occurs in field populations, hybrids with a YT maternal parent and YT cytoplasm would be more numerous than those with a DT female parent and DT cytoplasm. This would also suggest that pollen-mediated introgression of genetic material from DT into YT populations might be more common than gene flow in the reverse direction.

To track gene flow in this study, the chloroplast genome (cpDNA) was targeted for marker development because several characteristics of cpDNA make it preferable to the mitochondrial (mtDNA) or nuclear (ncDNA) genomes. With rare exceptions, cpDNA is uniparental and maternally inherited in angiosperms (Birky 2001; Corriveau and Coleman 1988). Therefore, using species-diagnostic cpDNA markers to determine whether a hybrid toadflax plant contains YT or DT cytoplasm will identify the female parent in the original hybridization event and track the direction of subsequent seed-mediated gene flow. Like cpDNA, mtDNA is maternally inherited in almost all angiosperms. However, the mitochondrial genome in plants is relatively large, with high rates of internal rearrangement, such as inversions, but low nucleotidesubstitution rates (Palmer and Hebron 1988; Ravi et al. 2008). This makes mtDNA less suitable than more highly conserved cpDNA as a source of molecular markers that will reliably differentiate between species without the complication of detecting large amounts of intraspecific variation.

There are currently no recommended management protocols for hybrid toadflax. The response of hybrid toadflax populations to herbicides has not, to our knowledge, been documented, and although the biocontrol agents Mecinus janthinus Germar and Dalmatian and Mecinus janthiniformis Toševski \& Caldara are widely released on YT and DT, respectively (Toševski et al. 2011), little is known about their efficacy on genetically complex (e.g., hybrid) toadflax populations. The research described 
Table 1. Locations of sampled toadflax populations. Isolated taxonomically unambiguous populations used for marker development indicated with asterisk $\left(^{*}\right)$.

\begin{tabular}{llrl}
\hline Taxon & \multicolumn{1}{c}{ Location } & Latitude & Longitude \\
\hline YT & Flat Tops Wilderness, CO* & $40.51 \mathrm{~N}$ & $105.22 \mathrm{~W}$ \\
YT & Fairbanks, AK* & $64.83 \mathrm{~N}$ & $147.78 \mathrm{~W}$ \\
YT & Pine Creek, MT & $45.06 \mathrm{~N}$ & $110.58 \mathrm{~W}$ \\
YT & Ovando, MT* & $47.02 \mathrm{~N}$ & $113.13 \mathrm{~W}$ \\
YT & Alta, WY & $43.75 \mathrm{~N}$ & $111.04 \mathrm{~W}$ \\
YT & Leola, SD & $45.67 \mathrm{~N}$ & $99.14 \mathrm{~W}$ \\
YT & Burlington, ND & $48.29 \mathrm{~N}$ & $101.51 \mathrm{~W}$ \\
DT & Lory State Park, CO & $40.57 \mathrm{~N}$ & $105.19 \mathrm{~W}$ \\
DT & Lee Martinez Park, & $40.57 \mathrm{~N}$ & $105.08 \mathrm{~W}$ \\
& $\quad$ Fort Collins, CO & & \\
DT & Cherry Street, & $40.56 \mathrm{~N}$ & $105.58 \mathrm{~W}$ \\
& Fort Collins, CO & & \\
DT & Helena, MT* & $46.60 \mathrm{~N}$ & $112.02 \mathrm{~W}$ \\
DT & Elkhorn Mountains, MT* & $46.27 \mathrm{~N}$ & $111.94 \mathrm{~W}$ \\
Hybrid & Boulder, MT & $46.23 \mathrm{~N}$ & $112.12 \mathrm{~W}$ \\
Hybrid & Radersberg, MT & $46.19 \mathrm{~N}$ & $111.63 \mathrm{~W}$ \\
Hybrid & Palisades, ID & $43.40 \mathrm{~N}$ & $111.21 \mathrm{~W}$ \\
Hybrid & Red Feather Lakes, CO & $40.80 \mathrm{~N}$ & $105.58 \mathrm{~W}$ \\
Hybrid & Horsetooth, CO & $40.55 \mathrm{~N}$ & $105.16 \mathrm{~W}$ \\
Hybrid & King County, WA & $47.45 \mathrm{~N}$ & $122.06 \mathrm{~W}$ \\
\hline
\end{tabular}

here is part of a broader effort to understand the population genetics of hybrid toadflax, with the goal of facilitating improved management of populations that may be more invasive than the parent species. The specific objectives of this research were (1) to develop cpDNA markers that reliably distinguish between YT and DT cytoplasm in invasive North American toadflax populations; and (2) to use those markers to determine the direction of pollen-mediated gene flow between YT and DT generating hybrid populations in the field.

\section{Materials and Methods}

PCR-RFLP Marker Development and Screening. As the complete plastome has not been sequenced in either YT or DT, candidate cpDNA marker regions were selected based on their reported polymorphic information content (PIC) in other angiosperms, as scored by Shaw et al. (2005). The five cpDNA regions chosen for further study were (1) trnL $c-d$ (see Taberlet et al. 1991 for primer sequences), (2) trnT-D, (3) rpS16, (4) trnS-trnfM, and (5) 59rpS12-rpL20 (primer sequences in Shaw et al. 2005). For initial PCRRFLP marker screening, 38 DT plants and 35 YT plants were sampled from morphologically unambiguous populations geographically isolated from the other species (see Table 1 for locations of all sampled populations). Total genomic DNA was extracted from each of these 73 plants using a Qiagen DNeasy mini prep kit, and a preliminary screen of the five selected cpDNA regions for possible PCR-RFLP markers was conducted using DNA from one plant from each toadflax species. Amplifications were performed in a Bio-Rad C1000 thermocycler using the following reaction mixture: $10 \mu$ Promega Gotaq reaction buffer, $0.5 \mathrm{mM}$ deoxynucleotide triphosphates (dNTPs), $0.25 \mu \mathrm{l}$ Promega Gotaq DNA polymerase, and $0.4 \mu \mathrm{M}$ each of forward and reverse primers. PCR parameters for the different amplified regions were as follows:

- $\operatorname{trnL} c$-d. $95 \mathrm{C}(203 \mathrm{~F})$ for $10 \mathrm{~min}$; then, 30 cycles of 95 $\mathrm{C}$ for $1 \mathrm{~min}$ and $53 \mathrm{C}$ for $30 \mathrm{~s}$; then, $72 \mathrm{C}$ for $45 \mathrm{~s}$, followed by a final annealing step at $72 \mathrm{C}$ for $10 \mathrm{~min}$.

- $\operatorname{trn} T-D .80 \mathrm{C}$ for $5 \mathrm{~min}$; then, 30 cycles of $94 \mathrm{C}$ for $45 \mathrm{~s}$; then, 52 to $58 \mathrm{C}$ for $30 \mathrm{~s}$; and $72 \mathrm{C}$ for $1 \mathrm{~min}$, followed by a final annealing step at $72 \mathrm{C}$ for $5 \mathrm{~min}$.

- rpS16. $80 \mathrm{C}$ for $5 \mathrm{~min}$; then, 35 cycles of $94 \mathrm{C}$ for $30 \mathrm{~s}$; then, 50 to $55 \mathrm{C}$ for $30 \mathrm{~s}$ and $72 \mathrm{C}$ for $1 \mathrm{~min}$, followed by a final annealing step at $72 \mathrm{C}$ for $5 \mathrm{~min}$.

- trnS-trnfM. $80 \mathrm{C}$ for $5 \mathrm{~min}$; then, 30 cycles of $94 \mathrm{C}$ for $30 \mathrm{~s}$; then, $55 \mathrm{C}$ for $30 \mathrm{~s}$ and $72 \mathrm{C}$ for $2 \mathrm{~min}$, followed by a final annealing step at $72 \mathrm{C}$ for $5 \mathrm{~min}$.

- 59rpS12-rpL20. $96 \mathrm{C}$ for $5 \mathrm{~min}$; then, 35 cycles of $96 \mathrm{C}$ for $1 \mathrm{~min}$; then, 50 to $55 \mathrm{C}$ for $1 \mathrm{~min}$ and $72 \mathrm{C}$ for 1 min, followed by a final annealing step at $72 \mathrm{C}$ for 5 min.

PCR products were visualized on a $1 \%$ agarose gel using ethidium bromide to determine quality of amplification. Each of these five amplified regions was then short run sequenced using an $\mathrm{ABI} 3130 \mathrm{xL}$ genetic analyzer (Thermo Fisher Scientific Life Sciences) with BigDye Terminator v 3. Serial Cloner 2.1 software (http://serial-cloner.en.softonic. com), which compares a DNA sequence against an extensive list of known restriction-enzyme target sites, was used to search the sequenced amplicons from both toadflax species for unique restriction sites. Based on results from the Serial Cloner sequence analysis, cpDNA regions trnL $c-d, r p S 16$, $\operatorname{trnS}$-trnfM, and 59rpS12-rpL20 were found to contain insufficient interspecific variation to generate species-diagnostic PCR-RFLP markers. However, species differentiation was observed in the sequenced $\operatorname{trn} T-D$ region, which was selected for further investigation with the candidate restriction enzymes Alu1, Accl, and Fokl.

Separate restriction digests of DNA from all $35 \mathrm{YT}$ and 38 DT plants were performed for each enzyme, each consisting of approximately $10 \mu \mathrm{g}$ total genomic DNA

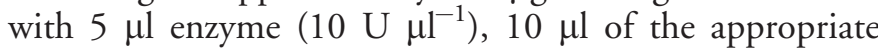
manufacturer-supplied buffer for each enzyme, and $75 \mu \mathrm{l}$ ultrapurified water. Digestions were carried out for $3 \mathrm{~h}$ at $37 \mathrm{C}$; digested DNA fragments were separated on a $3 \%$ 


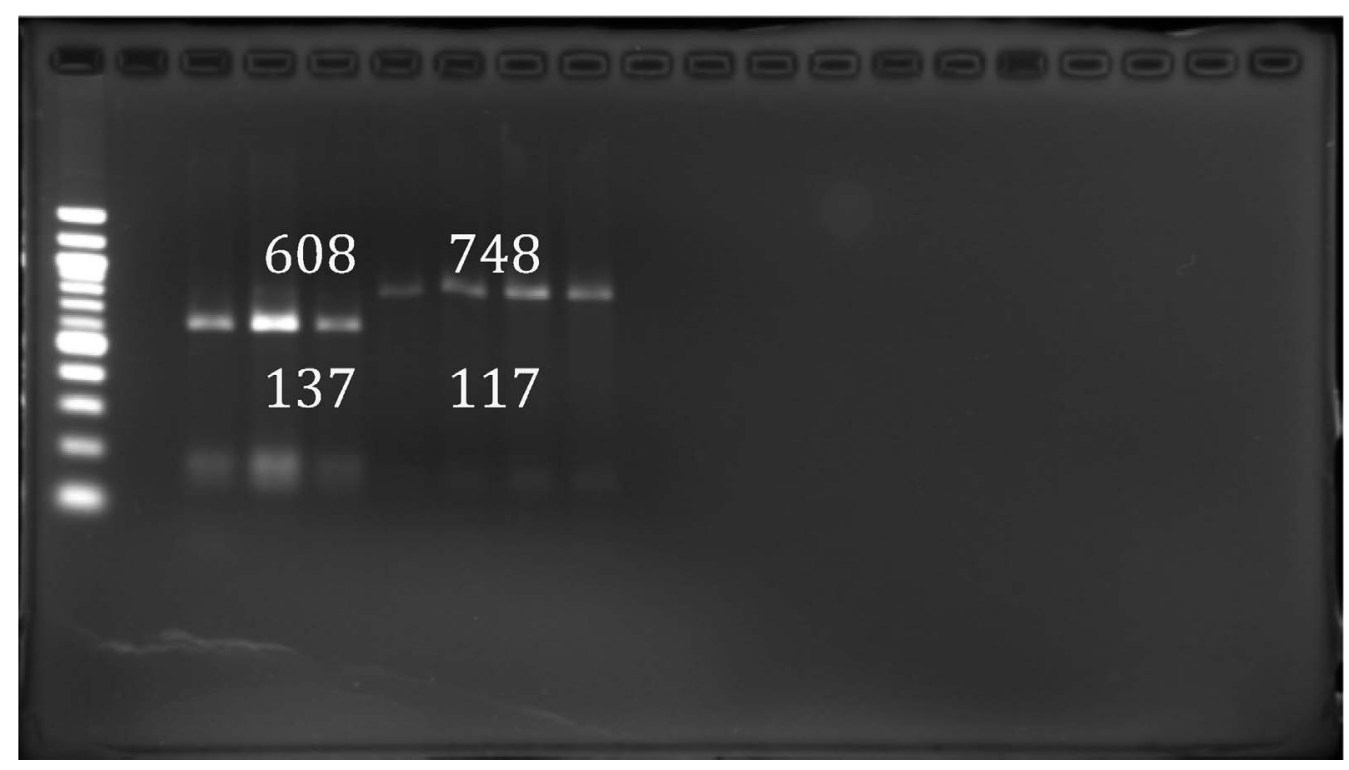

Figure 1. Alu1 digestion of the trnT-D plastid region in yellow toadflax (YT) and Dalmatian toadflax (DT). Approximate sizes of bands (bp) are shown. Lanes from left to right: (1) 1 kb ladder; (2) blank control (no DNA); (3) DT (Elkhorn Mountains, Montana); (4) DT (Helena, Montana); (5) DT (Helena, Montana); (6) YT (Flat Tops Wilderness, Colorado); (7) YT (Fairbanks, Alaska); (8) YT (Pine Creek, Montana); (9) YT (Ovando, Montana).

agarose gel and visualized using ethidium bromide. All restriction digests were repeated to confirm observed banding patterns. Accl and Fokl failed to generate species-specific restriction polymorphisms; however, digestion of the $\operatorname{trn} T-D$ region with Alu1 consistently generated clearly distinguishable restriction fragments of 748 base pairs (bp) and $117 \mathrm{bp}$ for all 35 YT plants and $608 \mathrm{bp}$ and $137 \mathrm{bp}$ for 25 of the DT plants tested (see Figure 1). This cpDNA PCR-RFLP marker was selected for screening hybrid toadflax populations. Haplotype sequences for the trnT-D amplicons have been deposited in GenBank and can be accessed online at http://www.ncbi.nlm.nih.gov/ genbank. Accession numbers are KX015823 for YT and KX015824 for DT.

DNA was extracted from an additional 71 plants collected from the hybrid field populations listed in Table 2 and from $64 \mathrm{~F} 1$ or $\mathrm{BC} 1$ hybrids derived from controlled greenhouse crosses using methods described by Ward et al. (2009). The presence of both YT and DT ncDNA in fieldcollected, putative hybrid plants was confirmed using species-diagnostic ISSR (intersimple sequence repeat) markers, as described in Ward et al. (2009). YT or DT cpDNA haplotypes were assigned to each individual based on Alu1 digestion of the amplified $\operatorname{trn} T-D$ region as described above. Pearson's chi-squared goodness-of-fit test was used to test for deviation from a $1: 1$ ratio for YT : DT cpDNA haplotypes within hybrid toadflax field populations (Fisher and Yates 1963).

\section{Plastid DNA Barcode Development and Screening.} Because there are no published identifying-barcode sequences for Linaria, the conserved gene regions $r b c L a$ and $\operatorname{mat} K$ were selected for this study, based on recommendations by Hollingsworth et al. (2011) for universal plant-barcoding regions. To increase the likelihood of identifying reliable cpDNA barcodes that would distinguish between YT and DT, the more variable intron/ intergenic plastid spacer regions trn-psbA and trnl-F were also selected for investigation because these regions have been reported to have high resolving power among other plant species (Kress and Erickson 2007; Lahaye et al. 2008; Liu et al. 2011). Total genomic DNA was extracted from 63 plants using a DNeasy DNA mini prep kit (Qiagen), as previously described. These 63 individuals were a subset of the 208 toadflax plants haplotyped using Alu1 digestion of the $\operatorname{trn} T-D$ region, as described above, and were selected to represent the sampled field populations and the controlledcross hybrids. Extracted DNA was amplified in a C1000 thermocycler with the following reaction components: 10 $\mu \mathrm{l}$ GoTaq reaction buffer (Promega), $0.5 \mathrm{mM}$ dNTPs, 0.4 $\mu \mathrm{M}$ upstream and downstream primers, $0.25 \mu \mathrm{l}$ GoTaq DNA polymerase (Promega), and ultrapurified, nucleasefree water for a final reaction volume of $50 \mu \mathrm{l}$. PCR parameters for the four plastid regions selected as potential barcoding sequences were as follows: 
Table 2. Plastid haplotypes of 144 field-collected toadflax plants based on Alu1 restriction of $\operatorname{trn} T-D$ region.

\begin{tabular}{|c|c|c|c|c|}
\hline Population & $\begin{array}{c}\text { Assigned taxon } \\
\text { (based on morphology) }\end{array}$ & $\begin{array}{l}\text { Plants with } \\
\text { YT haplotype }\end{array}$ & $\begin{array}{l}\text { Plants with } \\
\text { DT haplotype }\end{array}$ & $\begin{array}{l}\text { Chi-square test } \\
\text { for } 1: 1 \text { ratio }^{a}\end{array}$ \\
\hline Cherry Street, Fort Collins, CO & DT & 2 & 0 & N/A \\
\hline Elkhorn Mountains, MT & DT & 0 & 14 & N/A \\
\hline Helena, MT & DT & 0 & 5 & N/A \\
\hline Lee Martinez Park, CO & DT & 0 & 6 & N/A \\
\hline Lory State Park, CO & DT & 11 & 0 & N/A \\
\hline Alta, WY & YT & 5 & 0 & N/A \\
\hline Burlington, ND & YT & 3 & 0 & \\
\hline Leola, SD & $\mathrm{YT}$ & 5 & 0 & N/A \\
\hline Fairbanks, AK & $\mathrm{YT}$ & 7 & 0 & N/A \\
\hline Flat Tops, CO & $\mathrm{YT}$ & 9 & 0 & N/A \\
\hline Ovando, MT & $\mathrm{YT}$ & 6 & 0 & N/A \\
\hline Boulder, MT & Hybrid & 11 & 5 & $2.25(\mathrm{P}=0.86)$ \\
\hline Horsetooth, $\mathrm{CO}$ & Hybrid & 3 & 0 & $3.0(\mathrm{P}=0.07)$ \\
\hline King County, WA & Hybrid & 3 & 2 & $1.10(\mathrm{P}=0.71)$ \\
\hline Palisades, ID & Hybrid & 25 & 0 & $25.0(\mathrm{P}<0.001)$ \\
\hline Radersberg, MT & Hybrid & 13 & 7 & $1.80(\mathrm{P}=0.82)$ \\
\hline Red Feather Lakes, CO & Hybrid & 1 & 1 & $0.00(\mathrm{P}=0.99)$ \\
\hline
\end{tabular}

${ }^{a}$ Abbreviation: N/A, not applicable.

- matK (Lahaye et al. 2008). 5 min at 94 C; 40 cycles (1 min at $94 \mathrm{C}, 30 \mathrm{~s}$ at $48 \mathrm{C}, 1 \mathrm{~min}$ at $72 \mathrm{C}$ ), with a $7 \mathrm{~min}$ final extension at $72 \mathrm{C}$.

- $\operatorname{trnL}-F$ (Kress et al. 2005). 5 min. at 94 C; 35 cycles (1 min at $94 \mathrm{C}, 1 \mathrm{~min}$ at 50 to $55 \mathrm{C}, 2 \mathrm{~min}$ at $72 \mathrm{C}$ ), with a 10 min final extension at $72 \mathrm{C}$.

- rbcLa. (Kress et al. 2005): 5 min. At 95 C; 32 cycles (30 sec. At 95 C, $30 \mathrm{sec}$. At 53 to 55 C, $1 \mathrm{~min}$ at $72 \mathrm{C}$ ), with a 10 min final extension at $72 \mathrm{C}$.

- $\operatorname{trnH}$-psbA (Sang et al. 1997). 5 min at 95 C; 35 cycles (1 min at $95 \mathrm{C}, 45 \mathrm{~s}$ at $55 \mathrm{C}, 2 \mathrm{~min}$ at $72 \mathrm{C}$ ), with a $10 \mathrm{~min}$ final extension at $72 \mathrm{C}$.

Amplified DNA regions were run on a 1\% agarose gel, stained with ethidium bromide, and visually examined under ultraviolet light to confirm a single amplification product corresponding to that previously reported for each primer set. Amplified regions were then precipitated using the ethanol/ethylenediaminetetraacetic acid protocol provided in the BigDye Terminator v3.1 cycle sequencing kit, and short run sequenced using an $\mathrm{ABI} 3130 \mathrm{xL}$ genetic analyzer with ABI's BigDye Terminator v3.1. MEGA v5 software (http://www.megasoftware.net) was used to analyze the sequenced regions, and ClustalW v1.81(http:// www.clustal.org/clustal2/) was used for multiple sequence alignment. All aligned sequences were trimmed by excluding the first 50 to $70 \mathrm{bp}$ and the last 50 to $100 \mathrm{bp}$ because of their low signal strength on the chromatogram generated by the ABI 3130xL genetic analyzer.
Because the trnH-psbA and $r b c L a$ regions were polymorphic in $<50 \%$ of the screened accessions and polymorphisms were inconsistent across species, these sequences were discarded as unsuitable for barcoding. Haplotypes were assigned to screened individuals based on polymorphisms in the mat $K$ and trnL-F cpDNA regions and were compared with previously assigned haplotypes for the same individuals based on Alu1 digestion of the trnT-D region.

\section{Results and Discussion}

Haplotyping Based on PCR-RFLP Markers. Digestion of the $\operatorname{trn} T-D$ plastid region with Alu1 generated two distinct haplotypes. The YT haplotype consisted of two fragments of $748 \mathrm{bp}$ and $117 \mathrm{bp}$ and was found in all 35 taxonomically unambiguous YT plants collected from different populations in Alaska, Colorado, and Montana (Tables 1 and 2). The DT haplotype consisted of fragments of $608 \mathrm{bp}$ and $137 \mathrm{bp}$; Serial Cloner analysis of the sequenced trnT-D amplicon predicted an additional restriction site for Alu 1 producing a third 2 bp fragment, but this was too small to be used. The most reliable and easily visualized PCR-RFLP polymorphism distinguishing between the YT and DT haplotypes was the $748 \mathrm{bp}$ fragment for YT vs. the $608 \mathrm{bp}$ fragment for DT (Figure 1). Twenty-five morphologically unambiguous DT accessions, originating from two separate Montana populations, had the DT haplotype. However, two plants collected in 
Table 3. cpDNA haplotypes for 49 field-collected toadflax plants based on DNA barcode.

\begin{tabular}{|c|c|c|c|c|}
\hline Population & $\begin{array}{c}\text { Assigned taxon } \\
\text { (based on morphology) }\end{array}$ & $\begin{array}{l}\text { Barcoding regions } \\
\text { sequenced }\end{array}$ & $\begin{array}{l}\text { Plants with } \\
\text { YT haplotype }\end{array}$ & $\begin{array}{l}\text { Plants with } \\
\text { DT haplotype }\end{array}$ \\
\hline Alta, WY & YT & $\begin{array}{l}\operatorname{trnL} L-F \\
\operatorname{mat} K\end{array}$ & 4 & 0 \\
\hline Burlington, ND & YT & $\begin{array}{l}\operatorname{trnL} L-F \\
\operatorname{matK}\end{array}$ & $2^{\mathrm{a}}$ & 0 \\
\hline Fairbanks, AK & YT & matK & 2 & 0 \\
\hline Flat Tops Wilderness, CO & YT & $\operatorname{trn} L-F$ & 2 & 0 \\
\hline Leola, SD & YT & $\operatorname{trn} L-F$ matK & 4 & 0 \\
\hline Ovando, MT & YT & $\operatorname{trn} L-F$ matK & 3 & 0 \\
\hline Pine Creek, MT & $\mathrm{YT}$ & $\operatorname{trnL} L-F$ & 1 & 0 \\
\hline Cherry St Fort Collins, CO & DT & $\begin{array}{l}\text { trnl-F } \\
\text { matK }\end{array}$ & 2 & 0 \\
\hline Elkhorn Mountains, MT & DT & $\begin{array}{l}\operatorname{trnL} L-F \\
\operatorname{mat} K\end{array}$ & 0 & 4 \\
\hline Helena, MT & DT & $\begin{array}{l}\operatorname{trnL} L-F \\
\operatorname{matK}\end{array}$ & 0 & 4 \\
\hline Lee Martinez Fort Collins, CO & DT & $\operatorname{trn} L-F$ & 0 & 2 \\
\hline Lory State Park, CO & DT & $\begin{array}{l}\operatorname{trnL} L-F \\
\operatorname{matK}\end{array}$ & 3 & 0 \\
\hline Boulder, MT & Hybrid & mat $K$ & 3 & 2 \\
\hline Palisades, ID & Hybrid & $\begin{array}{l}\operatorname{trnL}-F \\
\operatorname{mat} K\end{array}$ & 4 & 0 \\
\hline Radersburg, MT & Hybrid & $\operatorname{trn} L-F$ mat $K$ & 4 & 1 \\
\hline Red Feather Lakes, CO & Hybrid & $\operatorname{trn} L-F$ & 1 & 1 \\
\hline
\end{tabular}

${ }^{a}$ One individual haplotyped as DT using trnL-F, YT using matK.

Fort Collins, CO (DT Cherry 1 and 2), and 11 plants collected in Lory State Park, CO, displayed the YT haplotype, although they were from isolated populations morphologically indistinguishable from and, therefore, assumed to be DT. TrnL-F barcoding of both Fort Collins plants and three of the Lory State Park accessions confirmed the YT haplotype (Table 3). These plants could be the result of YT $\times$ DT hybridization, followed by repeated backcrossing to DT, as discussed below.

Sixty-four hybrid offspring from controlled greenhouse crosses with known female parents were screened to further test the accuracy of haplotyping based on digestion of $\operatorname{trn} T$ $D$ with Alu1. All plants displayed the expected haplotype inherited from the recorded female parent (data not shown), except for eight individuals that had the YT haplotype, despite being the progeny of presumed DT maternal parents. Examination of the pedigrees of these plants showed that five were derived from crosses with presumed DT plants from the Lory State Park population as female parents. As described earlier, the putative DT population from Lory State Park appears to consist of backcrossed hybrids, containing YT cytoplasm that would have been transmitted to the progeny when these plants were used as female parents. The remaining three plants with the YT haplotype were half-sibs with different YT pollen parents but the same presumed DT maternal parent. This plant was collected from Cherokee Park Wildlife Area near Livermore, CO, and was initially identified as DT, based on morphology; it was also unusually large and was the only toadflax plant in the area. By the time this study was conducted, this maternal parent plant had died, and no tissue was available for haplotyping. However, its size, vigor, and transmission of the YT haplotype when used as a female parent indicate that it was most likely derived from a YT by DT hybridization with subsequent repeated backcrossing to DT pollen parents, resulting in a plant morphologically resembling DT but retaining YT cytoplasm. Similar plants were identified in the Lory State Park population.

Haplotyping Based on cpDNA Barcoding. The plastid region trnL-F proved to be the most useful barcoding sequence, with diagnostic SNPs at two sites that reliably distinguished between YT and DT. This region was sequenced in $16 \mathrm{YT}$ plants, collected from isolated taxonomically unambiguous populations in Wyoming, North Dakota, South Dakota, Idaho, Montana, and Colorado, which all had a guanine at positions 284 and 
Table 4. Haplotypes based on single nucleotide polymorphisms in the matK barcoding region.

\begin{tabular}{|c|c|c|c|c|c|c|c|c|c|}
\hline Population & $\begin{array}{l}\text { Morphological } \\
\text { taxon }\end{array}$ & Site 88 & Site 297 & Site 354 & Site 359 & Site 379 & Site 456 & Site 502 & Site 706 \\
\hline Leola, SD & YT & $\mathrm{C} \rightarrow \mathrm{G}$ & & $\mathrm{C} \rightarrow \mathrm{G}$ & $\mathrm{C} \rightarrow \mathrm{T}$ & $\mathrm{T} \rightarrow \mathrm{C}$ & & $\mathrm{T} \rightarrow \mathrm{C}$ & \\
\hline Burlington, ND & YT & $\mathrm{C} \rightarrow \mathrm{G}$ & & $\mathrm{C} \rightarrow \mathrm{G}$ & $\mathrm{C} \rightarrow \mathrm{T}$ & $\mathrm{T} \rightarrow \mathrm{C}$ & & $\mathrm{T} \rightarrow \mathrm{C}$ & \\
\hline Alta, WY & $\mathrm{YT}$ & & & & & & & $\mathrm{T} \rightarrow \mathrm{C}$ & \\
\hline Fairbanks, AK & YT & & $\mathrm{C} \rightarrow \mathrm{T}$ & & & & & & \\
\hline Pine Creek, MT & YT & & $\mathrm{C} \rightarrow \mathrm{T}$ & & & & & $\mathrm{T} \rightarrow \mathrm{C}$ & \\
\hline Helena, MT & DT & & & & & & $\mathrm{C} \rightarrow \mathrm{T}$ & & $A \rightarrow G$ \\
\hline Elkhorn Mountains, MT & DT & & & & & & $\mathrm{C} \rightarrow \mathrm{T}$ & & $A \rightarrow G$ \\
\hline
\end{tabular}

331. In contrast, 10 of 15 DT plants from similarly unambiguous populations possessed an adenine at those same positions. Five plants presumed to be DT based on morphology were sequenced and found to possess the YT haplotype with a guanine at positions 284 and 331. Three of these plants were from the Lory State Park population, and the other two were from the Cherry Street, Fort Collins, population (Table 3). All these individuals were also haplotyped as YT based on Alu1 digestion of trn T-D (Table 2); as already noted, plants from these populations are most likely backcrossed hybrids.

The mat $K$ region was sequenced in 15 YT plants from five different populations, 13 DT plants from four different populations, 14 field-collected hybrids from three different populations, and 5 controlled cross-hybrids. Screening these 47 plants revealed eight polymorphic sites: combined as a single barcode, SNPs across these eight sites could distinguish YT cpDNA from DT cpDNA for all accessions, except the DT Lee Martinez population (Table 4). The level of intraspecific variation based on SNPs at these sites makes matK less useful than $\operatorname{trnL}-F$ as a speciesidentifying barcode for toadflax, although barcoding at matK may be useful for population delineation. For this application, more extensive sampling would be needed to investigate the extent of within-population haplotype variation, which was beyond the scope of this study.

For the $49 \mathrm{YT}$, DT, and hybrid plants that were haplotyped based on both PCR-RFLP and barcoding, assignment of YT or DT haplotype was highly consistent across methods. Plants from each taxon investigated were assigned the same haplotype whether they were barcoded using $\operatorname{trn} L-F$ or $m a t K$, and these corresponded with the species-diagnostic haplotype based on Alul digestion of $\operatorname{trn} T-D$ in almost all plants screened using multiple methods. The single exception was a YT plant from the Burlington, ND, population, which was haplotyped as YT based on Alu1 digestion of trnT-D and on SNPs at three positions in the mat $K$ barcoding sequence but was haplotyped as DT based on one SNP in the trnL-F region. Because this plant clearly appeared to be YT based on its morphology and provenance from an isolated and taxonomically unambiguous YT population, this discrepancy was probably caused by a sequencing error in the trnL$F$ amplicon. Overall, species-diagnostic cpDNA haplotypes were highly consistent, whether assigned using Alu1 digestion of $\operatorname{trn} T-D$ or barcoding of $\operatorname{trn} L-F$, and matK was also highly consistent when sequenced as a supporting barcoding region.

Haplotype Frequency and Distribution. A key objective of this study was to determine whether the asymmetric gene flow observed in controlled greenhouse crosses also occurs in field populations, resulting in a higher proportion of hybrid toadflax plants with YT cpDNA. Our results suggest this might be the case: at none of the six field sites sampled, did hybrid plants with DT cpDNA outnumber those with YT cpDNA. At four sites, the numbers of plants in each category did not deviate significantly from a $1: 1$ ratio (Table 2), although this lack of statistical significance may reflect relatively small sample sizes. The exception was the hybrid toadflax population at Palisades, ID, where all 25 plants sampled had YT cpDNA. This site is also unusual in that neither parent species is present (S.E.S., personal observation). It is possible that an aggressively expanding hybrid swarm has completely displaced both YT and DT at this location. Alternatively, the present hybrid toadflax population could be derived from seed transported from elsewhere, possibly from a single hybridization event with YT as the female parent.

The presence of YT cpDNA in plants from two Colorado populations morphologically indistinguishable from DT suggests that introgression of YT genetic material into DT populations may be more widespread than previously realized. This cryptic hybridization further complicates the taxonomy of invasive DT in North America, which has been variously identified as $L$. dalmatica (L.) P. Mill. spp. dalmatica; L. dalmatica (L.) P. Mill. ssp. macedonica (Griseb.) D.A. Sutton; and broomleaf toadflax [Linaria genistifolia (L.) Mill. ssp. dalmatica (L.) Maire and Petitm.] (Chater et al. 1972; 
Davis 1978; Hartl 1974; Sutton 1988). DT and congeners L. genistifolia, Linaria rubioides (Vix. \& Pančić) Hayek; and broadleaf toadflax (Linaria grandiflora Desf.) have been posited as contributors to a potentially widespread native range species complex (Niketić and Tomović 2008). This or similar Linaria species complexes may be a source of the genetically diverse plants detected in our study. Linaria congeners may also be similarly prone to hybridization in North America. Narrow-leaved or broomleaf toadflax has been identified as a separate exotic species, L. genistifolia (Fernández-Mazuecos et al. 2013; Wilson et al. 2005); plants resembling DT with narrow leaves have also been confirmed as hybrids (Ward et al. 2009) or droughtstressed DT (S.M.W. and S.E.S., personal observation). Our results show that some invasive populations thought to be DT may, in fact, be backcrossed hybrids that have recovered many of the morphological and ecophysiological characteristics of the DT parent while retaining introgressed YT genes.

This cryptic hybridization has implications for biocontrol-based toadflax management. Stem-mining weevils from the genus Mecinus are widely released on invasive toadflax throughout the western United States. Mecinus janthiniformis exhibits a strong host preference for DT and does not readily establish on YT in the field. A recently confirmed cryptic congener, the YT stem-mining weevil $M$. janthinus, shows promise as a selective biocontrol agent for YT (Toševski et al. 2011, 2013). Cryptic hybridization resulting in apparent YT or DT populations containing introgressed genetic material from the other species could make such populations unacceptable as hosts for their presumed Mecinus species and may explain why at some locations of presumed DT invasion, repeated releases of $M$. janthiniformis, in particular, have been unsuccessful (S.E.S., personal observation).

Introgression of adaptive genes from a congeneric species may also increase the fitness, ecological amplitude, and invasive potential of backcrossed genotypes. Introgression resulting in the transfer of adaptive traits among congeners has been demonstrated in Helianthus species by Whitney et al. (2006), who proposed that range expansion of common sunflower (Helianthus annuus L.) in Texas was facilitated by the capture of alleles conferring herbivore resistance from cucumberleaf sunflower [Helianthus debilis Nutt. ssp. cucumerfolius (Torr. \& A. Gray) Heiser]. The YT cpDNA detected in some DT populations in this study may not itself confer an adaptive advantage. However, it is likely that past hybridization and backcrossing events indicated by the presence of this cpDNA have also introgressed potentially adaptive nuclear alleles from one toadflax species to the other. As noted earlier, YT and DT rarely co-occur in their native Eurasian ranges, and spontaneous hybridization between these toadflaxes has not been reported outside North
America (Ward et al. 2009). It seems likely, therefore, that gene flow between YT and DT is a recent phenomenon associated with, and facilitated by, their coinvasion of a novel North American range. The implications of such gene transfer for expanded invasion by both toadflax species deserve further investigation.

\section{Acknowledgments}

This research was supported by funds provided by the U.S. Department of Agriculture (USDA)-Forest Service, Rocky Mountain Research Station, under JVA 10-JV-11221632-225, and by USDA-National Institute of Food and Agriculture, Agricultural Experiment Station project COL00625. A.B. received financial support from the Colorado State University Program in Molecular Plant Biology.

\section{Literature Cited}

Alex J (1962) The taxonomy, history, and distribution of Linaria dalmatica. Can J Bot 40:295-307

Arnold RM (1982) Pollination, predation and seed set in Linaria vulgaris (Scrophulariaceae). Am Midl Nat 107:360-369

Birky CW (2001) The inheritance of genes in mitochondria and chloroplasts: laws, mechanisms, and models. Ann Rev Genet 35:125148

Brown LS (2008) Genetic Variation of the Invasive Linaria dalmatica in Its Introduced Range in Western North America and the Impact of Its Predominant Biological Control Agent, Mecinus janthinus. MS thesis. Moscow, ID: University of Idaho. $91 \mathrm{p}$

Chater AD, Valdés B, Webb DA (1972) Linaria Miller. Pages 226-236 in Tutin VG, Heywood VH, eds. Flora Europaea. Volume 3. Cambridge, U.K.: Cambridge University Press

Corriveau JL, Coleman AW (1988) Rapid screening method to detect potential biparental inheritance of plastid DNA and results for over 200 angiosperms. Am J Bot 75:1443-1458

Davis PH (1978) Flora of Turkey and the East Aegean Islands. Edinburgh, U.K.: Edinburgh University Press 826 p

De Clerck-Floate R, Richards KW (1997) Pollination ecology and biocontrol: developing release strategies for seed-feeding insects on Dalmatian toadflax. Acta Hortic 437:379-384

Fernández-Mazuecos M, Blanco-Pastor JL, Vargas P (2013) A phylogeny of toadflaxes (Linaria Mill.) based on nuclear internal transcribed spacer sequences: systematic and evolutionary consequences. Int J Plant Sci 174:234-249

Field DL, Ayre DJ, Whelan RJ, Young AG (2011) Patterns of hybridization and asymmetrical gene flow in hybrid zones of the rare Eucalyptus aggregata and common E. rubida. Heredity 106:841-853

Fisher RA, Yates F (1963) Statistical Tables: For Biological, Agricultural and Medical Research. 6th edn. Edinburgh, U.K.: Oliver and Boyd. $148 \mathrm{p}$

Hartl D (1974) Scrophulariaceae. Pages 78-81 in Hegi G, ed. Illustrierte Flora von Mitteleuropa. Munich: Carl Hanser Verlag

Hollingsworth PM, Graham SW, and Little DP (2011) Choosing and using a plant DNA barcode. PLoS One 6:e19254. DOI: 10.1371/ journal.pone.0019254 
Kress WJ, Erickson DL (2007) A two-locus global DNA barcode for land plants: the coding rbcL gene complements the non-coding trnH/ psbA spacer region. PLoS One 2:e508. DOI: 10.1371/journal.pone. 0000508

Lahaye R, van der Bank M, Bogarin D, Warner J, Pupulin F, Gigot G, Maurin O, Duthoit S, Barraclough TG, Savolainen V (2008) DNA barcoding the floras of biodiversity hotspots. Proc Natl Acad Sci USA 105:2923-2928

Lewis D, Crowe LK (1958) Unilateral interspecific incompatibility in flowering plants. Heredity 12:233-256

Liu J, Moller M, Gao LM, Zhang DQ, Li DZ (2011) DNA barcoding for the discrimination of Eurasian yews (Taxus L., Taxaceae) and the discovery of cryptic species. Mol Ecol Resour 11:89-100

Mack RN (2003) Plant naturalizations and invasions in the eastern United States: 1634-1860. Ann Mo Bot Gard 90:77-90

Muranishsi S, Tamaki I, Setsuko S, Tomaru N (2013) Asymmetric introgression between Magnolia stellata and M. salicifolia at a site where the two species grow sympatrically. Tree Genet Genomes 9:1005-1015

Niketić M, Tomović G (2008) Taxonomy and nomenclature of the Linaria genistifolia complex (Plantaginaceae-Antirrhineae) in S.E. Europe and Anatolia. Taxon 57:619-629

Palmer JD, Hebron LA (1988) Plant mitochondrial DNA evolves rapidly in structure, but slowly in sequence. J Mol Evol 28:87-97

Pauchard A, Alaback PB, Edlund EG (2003) Plant invasions in protected areas at multiple scales: Linaria vulgaris (Scrophulariaceae) in the West Yellowstone area. West N Am Naturalist 63:416-428

Rahme J, Widmer A, Karrenberg S (2009) Pollen competition as an asymmetric reproductive barrier between two closely related Silene species. J Evol Biol 22:1937-1943

Ravi V, Khurana JP, Tyagi AK, Khurana P (2008) An update on chloroplast genomes. Plant Syst Evol 271:101-122

Saner MA, Clements DR, Hall MR, Doohan DJ, Crompton CW (1995) The biology of Canadian weeds. 105. Linaria vulgaris Mill. Can J Plant Sci 75:525-537

Sang T, Crawford DJ, Stuessy TF (1997) Chloroplast DNA phylogeny, reticulate evolution and biogeography of Paeonia (Paeoniaceae). Am J Bot 84:1120-1136

Shaw J, Lickey EB, Beck JT, Farmer SB, Liu WS, Miller J, Small RL (2005) The tortoise and the hare II: relative utility of 21 noncoding plastid DNA sequences for phylogenetic analysis. Am J Bot 92:142166

Starr TN, Gadek KE, Yoder JB, Flatz R, Smith CI (2013) Asymmetric hybridization and gene flow between Joshua trees (Agavaceae: Yucca) reflect differences in pollinator host specificity. Mol Ecol 22:437-449

Sutton DA (1988) A Revision of the Tribe Antirrhineae. London: Oxford University Press. $584 \mathrm{p}$
Sutton J, Stohlgren T, Beck KG (2007) Predicting yellow toadflax infestations in the Flat Tops Wilderness of Colorado. Biol Invasions 9:783-793

Taberlet P, Gielly L, Pautou G, Bouvet G (1991) Universal primers for amplification of three non-coding regions of plastid DNA. Plant Mol Biol 17:1105-1109

Tiffin P, Olson MS, Moyle LC (2001) Asymmetrical crossing barriers in angiosperms. Proc R Soc Lond B Biol Sci 268:861-867

Toševski I, Jović J, Krstić O, Gassmann A (2013) PCR-RFLP-based method for reliable discrimination of cryptic species within Mecinus janthinus species complex (Mecinini, Curculionidae) introduced in North America for biological control of invasive toadflaxes. Biocontrol 58:563-573

Toševski I, Caldara R, Jović J, Hernández-Vera G, Baviera C, Gassmann A, Emerson BC (2011) Morphological, molecular and biological evidence reveal two cryptic species in Mecinus janthinus Germar (Coleoptera, Curculionidae), a successful biological control agent of Dalmatian toadflax, Linaria dalmatica (Lamiales, Plantaginaceae). Syst Entomol 36:741-753

Turner MF (2012) Viability and Invasive Potential of Hybrids between Yellow Toadflax (Linaria vulgaris) and Dalmatian Toadflax (Linaria dalmatica). Ph.D. dissertation. Fort Collins, CO: Colorado State University. $130 \mathrm{p}$

[USDA-NRCS] U.S. Department of Agriculture-Natural Resources Conservation Service (2016) Plants Database. http://plants.usda.gov. Accessed April 1, 2016.

Vujnovic K, Wein RW (1997) The biology of Canadian weeds. 106. Linaria dalmatica (L.) Mill. Can J Plant Sci 77:483-491

Ward SM, Reid SD, Harrington J, Sutton J, Beck KG (2008) Genetic variation in invasive populations of yellow toadflax (Linaria vulgaris) in the western United States. Weed Sci 56:394-399

Ward SM, Sing SE, Turner MF, Fleischmann CE (2009) Hybridization between invasive populations of Dalmatian toadflax (Linaria dalmatica) and yellow toadflax (Linaria vulgaris). Invasive Plant Sci Manag 2:369-378

Whitney KD, Randell RA, Riesebery LH (2006) Adaptive introgression of herbivore resistance traits in the weedy sunflower Helianthus annuus. Am Nat 167:794-807

Wilson L, Sing SE, Piper GL, Hansen RW, De Clerck-Floate R, MacKinnon DK, Randall CB (2005) Biology and Biological Control of Dalmatian and Yellow Toadflax. Morgantown, WV: USDA Forest Service

Received January 12, 2016, and approved April 6, 2016.

Associate Editor for this paper: John F. Gaskin, USDA-ARS

120 - Invasive Plant Science and Management 9, April-June 2016 